\title{
A imprensa de cunho literário no extremo-sul brasileiro: um estudo de caso da história da Inúbia e uma brevíssima incursão à crítica literária
}

\author{
Literary press in the Brazilian extreme south: a case study of the Inúbia history \\ and a very brief incursion into literary criticism
}

FRANCISCO DAS NEVES ALVES

Universidade Federal do Rio Grande - Rio Grande - Rio Grande do Sul - Brasil

Resumo: A partir da segunda metade do século XIX, a imprensa no Brasil passou por uma fase de ampla expansão. Nessa época, o jornalismo brasileiro passaria por uma etapa de diversificação e crescente especialização, surgindo periódicos com propostas editoriais e/ou voltados a públicos específicos. Foi nesse contexto que ocorreu um impulso da imprensa literária, notadamente nas maiores comunidades do país, caso da mais meridional província nacional e, em tal âmbito, em uma de suas mais importantes cidades, a do Rio Grande. Nessa localidade portuária, uma das mais progressistas no Rio Grande do Sul de então, circularam várias publicações literárias, que buscavam voltar seus textos essencialmente para a difusão da cultura e o incentivo à leitura, servindo muito a contento para a divulgação não só de escritores que contavam com reconhecimento internacional e nacional, mas também aqueles vinculados à literatura regional e local, auxiliando na propagação da literatura sulina de então. Este trabalho visa analisar a imprensa literária rio-grandina, com especial atenção para um de seus representantes - a Inúbia, mormente no que tange à sua história, suas propostas editoriais e suas dificuldades para manter a circulação, além de realizar uma breve incursão à prática de uma crítica literária por parte do periódico.

Palavras-chave: Imprensa; Literatura; História; Rio Grande do Sul

\begin{abstract}
From the second half of the nineteenth century, the press in Brazil went through a phase of wide expansion. At that time, the Brazilian journalism go through a stage of diversification and increasing specialization, emerging journals with editorial proposals and/or targeted to specific audiences. It was in this context that there was a surge of literary press, especially in the larger communities of the country, where the southernmost national province and in such a context, in one of its most important cities, the Rio Grande. In this port town, one of the most progressive in Rio Grande do Sul then circulated several literary publications, seeking back your texts primarily for the dissemination of culture and encouraging reading, much to the satisfaction serving for the dissemination not only of writers who relied on international and national recognition, but also those linked to regional and local literature, aiding in the spread of southern literature then. This work aims to analyze the rio-grandina literary press, with special attention to one of his representatives - the Inúbia, especially with regard to its history, its editorial proposals and their difficulties to maintain circulation, and perform a brief foray to the practice of a literary criticism by the journal.
\end{abstract}

Keywords: Press; Literature; History; Rio Grande do Sul 
Durante o século XIX, a literatura exerceu grande influência no seio das práticas jornalísticas. Nessa época, as áreas do saber humano encontravam-se ainda numa fase de definição em suas fronteiras, com plena interação entre os conhecimentos literários, históricos, sociológicos, antropológicos, políticos, econômicos e jornalísticos, entre tantos outros. De acordo com tal perspectiva, a imprensa periódica aparecia como um fator de difusão de tais conhecimentos, promovendo a divulgação daquilo que se convencionava denominar de letras, de modo a, figurativamente, espalhar a luz do conhecimento para desanuviar as trevas do obscurantismo. A literatura era tão abrangente que mesmo entre os periódicos predominantemente noticiosos ou políticos, havia a tradição de incluir também o vocábulo "literário" em muitos dos dísticos que ostentavam em seus frontispícios.

Se a literatura ganhava relevo nas páginas do jornalismo em geral, a partir do processo de especialização da imprensa, pelo qual surgiam publicações voltadas especificamente à divulgação de uma temática em particular ou a atender um público alvo mais específico, tal relevância se tornaria ainda mais marcante com o desenvolvimento de um periodismo essencialmente literário. Voltados à difusão das letras, do conhecimento e da cultura, os jornais de natureza literária espalharamse pelo mundo, não sendo diferente no Brasil, em cujas principais cidades circularam esses periódicos. Tal irradiação também seria promovida na mais meridional das províncias brasileiras, o Rio Grande do Sul, notadamente nas suas comunidades mais desenvolvidas, caso da cidade portuária do Rio Grande, dotada de considerável atividade jornalística no conjunto da qual foram editadas várias publicações de cunho literário.

A cidade do Rio Grande, ao longo do século XIX, foi uma das mais importantes do Rio Grande do Sul, atuando decisivamente no escoamento da produção pecuária sul-rio-grandense e na entrada das importações. Esse contexto de significativo crescimento econômico, avanço urbano, expansão populacional e relativo progresso cultural tornou-se campo razoavelmente fértil às práticas jornalísticas que evoluíram consideravelmente junto à comunidade rio-grandina, durante aquela época, e o próprio desenvolvimento da imprensa também serviu à caraterização da cidade como um dos referenciais de progresso na sociedade rio-grandense. Acompanhando o fato que a cidade do Rio Grande desempenhou papel primordial no contexto rio-grandense-do-sul, a imprensa rio-grandina foi uma das mais destacadas da província e mesmo do Brasil, tanto pela quantidade, quanto pela qualidade de seus periódicos. Assim, além de ter sido uma das primeiras localidades gaúchas a possuir jornais, o Rio Grande teve algumas das mais perenes folhas em termos provinciais, as quais chegaram a circular por mais de sete décadas. Nesse sentido, o jornalismo praticado na cidade portuária acompanhou pari passu e de modo muito próximo, a evolução do conjunto da imprensa brasileira daquela centúria.

O Porto do Rio Grande não representou apenas a porta da província em termos do comércio de mercadorias, servindo também à circulação de informações, ideias e opiniões, pois, durante significativo período, as notícias chegavam ao sul, através das correspondências e dos jornais vindos do Rio de Janeiro e da Europa, transportados em navios, por meio do Rio Grande. Era ainda comum a reprodução de notícias de periódicos do centro do país e estrangeiros, e a recíproca também era verdadeira, uma vez que jornais porto-alegrenses e até da Corte reproduziam informações e opiniões expressas pelas folhas rio-grandinas. Além disso, havia também um intercâmbio entre os jornalistas, pois muitos dos escritores públicos que atuaram no Rio Grande, já haviam trabalhado ou viriam a atuar em atividades jornalísticas no centro do país. Ao lado dessa circulação de notícias, a imprensa rio-grandina atuou constantemente na emissão e construção de uma prática discursiva, dando voz aos mais variados grupos sociais que atuaram no contexto regional e nacional.

Nesse quadro, a evolução da imprensa rio-grandina, no século XIX, acompanhou o processo de desenvolvimento do jornalismo brasileiro e, mormente, do gaúcho, tanto no aspecto cronológico quanto nas estruturas de organização e sustentação. Mesmo com alguma defasagem com relação aos progressos das atividades jornalísticas na capital imperial, o jornalismo na cidade do Rio Grande desenvolveu-se de modo coetâneo com o da maior parte da conjuntura nacional e chegou a ser pioneiro, se relacionado com o contexto regional. Dessa maneira, em tal época, a imprensa rio-grandina desenvolveu-se num processo em que podem ser identificadas três fases: a primeira, entre 1832 e 1845 , foi marcada pelas origens das atividades jornalísticas na cidade; a segunda, desde a metade da década de quarenta até o final da de sessenta, caracterizou-se por um crescimento e diversificação dos periódicos, surgindo então a maior parte dos diários rio-grandinos de maior longevidade; e a terceira, nas três últimas décadas do século XIX, quando deu-se um processo de amplo desenvolvimento e apogeu do jornalismo rio-grandino, até os prenúncios da crise que culminaria com o declínio, na virada daquela centúria para a seguinte.

Foi na conjuntura de disputas político-partidárias e de crise revolucionária da época regencial que ocorreu a gênese da imprensa na cidade do Rio Grande, marcada pelo tenso clima político da formação do Estado Nacional Brasileiro e pelos confrontos partidários e ideológicos dos quais resultaria a Revolução Farroupilha. Desenvol- 
veu-se, então, a primeira fase do jornalismo rio-grandino que, refletindo o clima de embates do momento, foi essencialmente político-partidário. Os jornais, mesmo que com níveis de aproximação variáveis, tiveram uma íntima relação com a preparação da guerra civil, manifestando-se, assim, através dos periódicos, o confronto entre rebeldes e legalistas, numa verdadeira batalha de palavras. Certas folhas ainda intentaram pautar sua linha editorial na neutralidade, na equidistância, na moderação e na conciliação, entretanto, essa imprensa que visava certa neutralidade não encontrou muito espaço para desenvolver-se, tendo em vista o amplo predomínio do jornalismo político-opinativo.

Após um avanço inicial, a crise advinda da guerra levaria a um refluxo da imprensa e somente a partir de 1845, com a pacificação provincial, ela seria retomada na cidade do Rio Grande. Tal renascimento do jornalismo, acompanhando a recuperação econômica e a estabilidade política, constituía-se no prenúncio da nova fase de crescimento e diversificação na qual entraria a imprensa rio-grandina. Nessa segunda etapa, diferenciando-se da fase anterior, ocorreria um arrefecimento dos debates políticos por meio dos jornais. Ainda assim, o periodismo crítico-opinativo não deixou de existir e viria a pronunciarse através de uma série de folhas de pequeno formato, circulação extremamente irregular, duração efêmera e que utilizavam, na maioria das vezes, um palavreado chulo e virulento, eram os pasquins. Nessa época, diversificavase a imprensa rio-grandina e, junto de tal pasquinagem, circularam folhas dedicadas a um jornalismo mais informativo, os noticiosos, e periódicos preocupados com a propagação cultural, através da divulgação da literatura. Nesse momento, apareceram também os jornais mais perenes de circulação diária, como o Diário do Rio Grande, O Comercial, o Eco do Sul e o Artista que, se consolidando na fase seguinte, viriam a representar a grande imprensa rio-grandina da época.

Dessa maneira, tal fase caracterizou-se por ser uma etapa de transição nas atividades jornalísticas, marcada por uma evolução nas técnicas da produção do jornal, sendo aprimorada a qualidade das folhas e estabelecido um sistema mais rentável de distribuição e venda dos números avulsos e das assinaturas. Como etapa de transição, a segunda fase da imprensa rio-grandina guardou características tanto da que lhe antecedeu, quanto daquela que lhe sucederia, pois, através dos pasquins, permaneceu o jornalismo opinativo, calcado no debate, porém com a supremacia das discussões pessoais sobre as políticas; e, através de uma diversificação das práticas jornalísticas, foram dados os passos iniciais em direção a uma especialização da imprensa, típica da terceira fase. Os avanços quantitativos, marcadamente no que se referiu aos pasquins, e qualitativos, mais especificamente dos noticiosos e literários, anunciavam também o terceiro período, o de maior desenvolvimento do jornalismo riograndino.

A terceira fase da imprensa rio-grandina correspondeu a um processo marcado pelo apogeu do jornalismo praticado na cidade, durante as três últimas décadas do século XIX, até o declínio das atividades jornalísticas, nos primórdios da centúria seguinte. Essa etapa de amplo desenvolvimento reproduzia o fenômeno que caracterizava tanto a imprensa brasileira quanto a sul-rio-grandense, ocorrendo uma representativa expansão das práticas jornalísticas por todo o país, além do que os jornais passaram por constantes melhorias na sua elaboração, no aprimoramento tecnológico das tipografias, no aumento do formato, na maior eficiência na distribuição e na ampliação da matéria publicitária. Circulavam, nessa época, desde os jornais diários, já bem estruturados e garantindo uma distribuição regular, até uma grande quantidade de pequenas folhas, em geral pouco perenes e de circulação irregular, refletindo suas dificuldades de organização e sustentação.

Nesse sentido, desde o final dos anos sessenta até a década de noventa, ocorreu um vasto crescimento nas atividades jornalísticas. A maioria dos diários se consolidou nesse período, vivendo suas fases mais prósperas. Até mesmo alguns dos representantes da pequena imprensa conseguiram níveis de organização e tempo de sobrevivência até então não atingidos por esse tipo de publicação. Ao lado desse novo avanço quantitativo-qualitativo, ocorreu também na cidade portuária uma diversificação ainda mais profunda que na fase anterior, passando o jornalismo por uma etapa de especialização, surgindo periódicos que visavam atender mais especificamente a determinados grupos ou segmentos da sociedade. A implantação da república e as consequentes crises políticas e econômicas, além do acirramento da repressão e do cerceamento ao jornalismo, levariam o mesmo a um de declínio. Era uma fase na qual a concorrência se tornaria ainda mais acirrada, e somente resistiram os periódicos que melhor se adaptaram a essa nova etapa. Davam-se então os primórdios da denominada imprensa empresarial, fase caracterizada por um processo cada vez mais crescente de concentração das atividades jornalísticas, passando a predominar as grandes empresas, em detrimento da imprensa artesanal, num processo que se acentuaria irremediavelmente durante o século XX.

Em meio às etapas de expansão da imprensa na cidade do Rio Grande, haveria espaço para o desenvolvimento de um jornalismo literário. A divulgação de matéria literária constituiu uma tradição junto ao periodismo riograndino, mormente nos jornais diários que, desde cedo, dedicaram certo espaço em suas páginas para apresentar trechos de obras literárias, através da seção "Folhetim". 
Tal seção, no entanto, destinava-se, essencialmente, a divulgar escritos de autores estrangeiros ou de renomados escritores brasileiros, ou seja, os "clássicos" da literatura, não ocorrendo maiores oportunidades para os poetas e prosadores da conjuntura local ou regional. Além disso, os folhetins eram apresentados ao "pé-depágina" e apareciam - ou desapareciam - de acordo com o espaço disponível, não chegando a ser considerados como um tipo de matéria imprescindível ao conjunto editorial da publicação. A seção destinada aos folhetins caracterizava-se ainda por uma simples transcrição das obras, não havendo nenhuma preocupação em abordar mais profundamente ou discutir aspectos ligados mais intrinsicamente à literatura.

Foi somente a partir do final da década de sessenta que passou a desenvolver-se um jornalismo essencialmente vinculado à divulgação literária. Repetindo um fenômeno que se dava nas maiores cidades do país (SODRÉ, 1999: 196-199), as folhas literárias eram, normalmente, iniciativa dos próprios autores ou de indivíduos ligados à difusão da literatura. Esses periódicos surgiam numa fase de transformação das práticas jornalísticas, respondendo a uma nova conjuntura socioeconômica e política que se anunciava, na qual as preocupações com a cultura, as ciências e as humanidades se encontravam em embrião, fomentando a procura por material de leitura e atualidade capaz de desenvolvê-lo. Assim, as publicações literárias se gestaram nesse contexto social, especializandose progressivamente no atendimento dessas novas necessidades (RÜDIGER, 2003: 60). Nesse sentido, o surgimento dessa imprensa literária inseriu-se num processo de desenvolvimento cultural da cidade do Rio Grande, no qual a imprensa desempenhava significativo papel na demonstração de que a porta de entrada da província era também bafejada pelos princípios básicos da civilização, conforme os padrões europeus (ALVES, 1999a:49).

Dessa forma, as folhas literárias se espalhavam pela Corte e pelas províncias, servindo à difusão cultural em meio ao público leitor. $\mathrm{O}$ jornalismo de ponta realizado na cidade do Rio Grande reproduziria tais práticas, circulando junto dessa comunidade alguns dos mais importantes periódicos literários do Rio Grande do Sul. Nesse quadro, o desenvolvimento da literatura rio-grandense do século XIX esteve intimamente vinculado ao aparecimento da imprensa, pois tais publicações tiveram efetiva influência na produção literária da província e na sua consequente divulgação, uma vez que os primeiros autores riograndenses recorriam aos órgãos de imprensa devido às grandes dificuldades que encontravam para a publicação e difusão de suas obras (BAUMGARTEN, 1980:12). Foram divulgados nos jornais literários rio-grandinos trabalhos dos mais representativos autores rio-grandenses, bem como romances, contos, textos críticos e correspondência entre homens ligados ao movimento cultural da província (BAUMGARTEN, 1982:26-27). Assim, esses jornais tiveram fundamental importância para o enriquecimento cultural sul-rio-grandense, permitindo uma maior popularização da incipiente literatura local e regional.

A primeira e mais importante folha literária riograndina foi a Arcádia, editada na cidade, entre maio de 1867 e julho de 1869. Era um periódico semanal "literário, histórico e biográfico", pretendendo ser também "ilustrado", mudando mais tarde seu dístico para "jornal consagrado à literatura". Impresso, no início, na Tipografia do Diário do Rio Grande e, posteriormente, em tipografia própria, em suas páginas foram publicados trabalhos assinados por aqueles que viriam a constituir a primeira geração importante de intelectuais gaúchos (BAUMGARTEN, 1999:44) e sua publicação revelava o admirável espírito de luta dessa geração (CESAR, 2006:179). Esse periódico utilizava uma técnica de edição diferenciada em relação aos demais jornais rio-grandinos, de modo que cada um dos exemplares correspondia a um fascículo, cuja reunião permitia a elaboração de uma espécie de livro, desenvolvendo-se em "séries" correspondentes a cada um dos anos de sua existência. Ainda no final da década de sessenta, circulou na cidade portuária, entre março e novembro de 1868, a Inúbia, uma publicação dominical, editada na Tipografia do Artista, sendo seus proprietários alguns dos empregados desse estabelecimento.

Nas três últimas décadas do século XIX, até a virada para a centúria seguinte, ainda que não tenham atingido a expressão das folhas da década de sessenta, notadamente a da Arcádia (ALVES, 2002:142), mantiveram-se as publicações ligadas à literatura. Nessa época, circulou $A$ Grinalda (1870-1871), um "periódico literário, crítico e recreativo", editado semestralmente por operários do Eco do Sul e impresso na tipografia desse jornal. A Violeta (1878-1879) foi outro "periódico literário, instrutivo e recreativo", uma edição dominical, publicada em tipografia própria. Mantendo a tradição da divulgação literária, foi publicado também o Arauto das Letras (1882-1883 e 1889), um "órgão dedicado à mocidade riograndense" que foi editado, inicialmente, na Tipografia do Comercial e, posteriormente, em tipografia própria. Outro "jornal crítico, literário e noticioso" foi o hebdomadário A Lanterna (1893-1894), e, já ao final da centúria, foi editado o Correio Literário (1900), outra folha dominical, impressa em oficina própria. Adentrando os primórdios do século XX, foi publicado O Recreio (1901), jornal semanal apresentado como "órgão da mocidade", impresso na tipografia de $A$ Razão.

Uma das grandes preocupações dos jornais literários esteve ligada ao constante intento de demonstrar que suas 
propostas eram essencialmente culturais, não devendo suas páginas destinar espaço a outro tipo de matéria que não fosse aquela voltada à literatura e à arte. Esse objetivo das folhas literárias esteve associado à busca por uma superação da pasquinagem, então bastante em voga, bem como ao objetivo de tornar-se progressivamente uma alternativa ao jornalismo político-partidário predominante em significativa parte da existência da imprensa gaúcha e rio-grandina. Ao lado dos noticiosos, os literários procuraram romper com a situação então vigente, especializando-se na difusão cultural e na discussão de assuntos de atualidade sem compromisso doutrinário (RÜDIGER, 2003:44). Era, assim, uma tentativa de criar um jornalismo alternativo à prática intrinsecamente opinativa que marcava a imprensa até aquele momento.

Nesse sentido, a Arcádia foi uma das que mais se preocupou em demarcar sua seara estritamente literária, afirmando estar alheia ao rumor contínuo em que se agitava o jornalismo em geral e, ao encerrar sua primeira série, orgulhava-se de ter cumprido à risca o seu programa, não arredando um só passo do caminho que prometeu seguir - sempre exclusivamente literária. Tal folha chegou a criticar às demais publicações literárias que não teriam seguido o mesmo caminho, enfatizando que a ela haviam se sucedido na província outros pequenos periódicos que se inculcavam literários, mas poucos foram os que perseveraram em bons princípios. Diante disso, a Arcádia lamentava que alguns deles, aberrando suas doutrinas, acabaram por se tornar vozes isoladas de paixões pessoais ou postes infamantes nos quais honras e reputações eram jungidas. Já na sua última edição rio-grandina, o periódico literário ainda chamava atenção para que não viesse a ser confundido com os pasquins que então circulavam em larga escala, ao dizer que ninguém vira a Arcádia imergir-se nos pauis da calúnia e da intriga, uma vez que tomara sempre para o seu procedimento a rasoura da imparcialidade e da justiça, permanecendo, portanto, como uma heroína da pugna literária (ARCÁDIA, 12 maio 1867 , p. 5-7, 299-302; 16 fev. 1868, p. 5-7; 19 jul. 1869, p. 300-302).

A isenção quanto à prática da pasquinagem também era destacada pela Violeta, ao afirmar que acreditava fielmente ter cumprido com o seu programa, apesar de ser forçoso confessar que a muitos havia desagradado, visto não se ocupar da vida alheia (VIOLETA, 22 set. 1878, p. 2). Os jornais literários da virada do século buscavam manter essa proposta de divulgação de matérias exclusivamente ligadas à literatura, caso de $O$ Recreio que, na sua edição de estreia, apresentava-se afirmando que o aparecimento de tal semanário não significava, nem representava um acontecimento na república das letras, porquanto os seus guias, os que o iriam conduzir pela estrada já percorrida por outros, não sonhando com a conquista de glórias, só visavam trabalhar para o engrandecimento de tudo quanto era belo e grandioso e que se resumia nas artes, na música e na poesia (O RECREIO, 18 ago. 1901, p. 1). O Arauto das Letras dizia adotar por bandeira o lema da liberdade pela instrução, buscando divulgar trabalhos de escritores que se distinguissem dignamente nas lides literárias (ARAUTO DAS LETRAS, 13 ago.1882, p. 1). Nesse contexto as folhas literárias rio-grandinas que circularam na segunda metade do século XIX buscaram demarcar o seu território, na prática de um jornalismo mais ameno, voltado à erudição e à cultura, em oposição às folhas de caráter opinativo que sustentaram os mais variados embates político-partidários e/ou pessoais, típicos da formação histórica sul-rio-grandense.

Demonstrar os desafios e obstáculos à continuidade da circulação foi outra das caraterísticas que marcou as folhas literárias de então. As iniciativas ligadas ao jornalismo literário estiveram quase sempre vinculadas às práticas da pequena imprensa, ou seja, eram periódicos, em geral, de pequeno formato, distribuição não-diária e que apresentavam sérias dificuldades na manutenção de sua circulação regular. Normalmente, eram folhas de confecção artesanal nas quais um único indivíduo executava as mais variadas funções, desde a elaboração até a distribuição do produto final. Muitas vezes sem empregados, era o próprio proprietário quem se encarregava da redação, da formatação, do trabalho tipográfico e das vendas dessas folhas, as quais nem sempre eram impressas em oficinas próprias, dependendo de serviços de terceiros para imprimirem seus jornais. Nesse sentido, a imprensa literária apresentou esse caráter de ser fomentada a partir de iniciativas individuais que, apesar das constantes dificuldades e das condições às vezes precárias, conseguiram manter a circulação de periódicos de razoável qualidade editorial, apesar da pouca perenidade.

Nessa linha, a Arcádia afirmava que, impossibilitada de admitir operários, pelo pequeno número de subscritores, constantemente fora o seu proprietário quem se encarregara do trabalho tipográfico, da impressão e, algumas vezes, até da distribuição, além da contribuição intelectual na forma das várias matérias estampadas nas páginas do periódico. $\mathrm{O}$ editor do jornal reclamava também do pouco interesse demonstrado pela população, comparando o incentivo dado à literatura em Portugal, ao passo que, no Rio Grande daquele momento, quase o inverso se passava, uma vez que a emulação se transformava em egoísmo e, em vez de apoio, aparecia a inveja esculpida nos tipos da ignorância, de qualquer forma predominando sobre a inteligência e, por conseguinte, sorvendo-lhe a seiva que a poderia nutrir. Na sua última edição publicada no Rio Grande, a Arcádia afirmava que sua tarefa fora árdua para vencer os percalços colocados à frente da continuidade de seu 
jornal, que teve de francamente resistir ao indiferentismo da época, aos golpes traiçoeiros de invejosos desafetos, ao murmúrio dos maldizentes, superando todos esses miseráveis empecilhos e seguindo ovante pela estrada do útil e do bem, deixando à retaguarda os zoilos a morderem-se de raiva, numa atitude considerada como plena de glória e de heroísmo (ARCÁDIA, 1867, p. 299302; 16 fev. 1868, p. 5-7; 19 jul.1869, p. 300-302).

A falta de interesse pela leitura também foi destacada pela Violeta ao afirmar que a cada momento ouvia-se falar em progresso, civilização, amor ao estudo, porém embalde quando os mesmos vinham a ser procurados, não se sabia onde se ocultavam, uma vez que a maior parte da mocidade detestava as letras porque lhe aborrecia o estudo. Apesar disso, ressaltava a folha literária que, como todas as regras tinham exceção, conseguia-se, lutando com algumas dificuldades manter a existência de jornaizinhos literários. Na mesma linha, o semanário completava tal ideia, desejando que não se zangassem com ele aqueles em que coubesse a carapuça e aceitassem os seus cordiais agradecimentos os que com suas valiosas proteções vinham concorrendo para que se pudesse cultivar aquela frágil e pequena flor, como lembrava o título do jornal (VIOLETA, 22 set. 1878, p. 2). A esse respeito, o Arauto das Letras, referindo-se à arte em geral, afirmava que os empreendimentos artísticos tinham de enfrentar um campo pouco fértil à cultura, onde se tratava em geral, com pouca humanidade qualquer trabalho mental, criado no contexto regional, quando isso deveria ser justamente o inverso do usual proceder (O ARAUTO DAS LETRAS, 27 jan.1889, p. 1).

Outra dificuldade na manutenção das folhas literárias esteve ligada ao inadimplemento dos assinantes, que praticamente inviabilizavam a solitária forma de arrecadação dessa imprensa. Nesse sentido, a Violeta publicava aviso, no qual rogava a todos os seus favorecedores tanto da cidade do Rio Grande como de fora dela que ainda se achavam em débito com aquela pequena empresa, o obséquio de mandarem quanto antes satisfazer suas assinaturas. Ainda a respeito do problema da distribuição e do pagamento das assinaturas, a mesma folha editou uma nota, sob o título "Procedimento inqualificável", explicando que só assim se poderia chamar aquele que haviam acabado de ter com os responsáveis pela publicação os assinantes residentes na vizinha cidade de Pelotas. Passava então a detalhar o ocorrido, destacando que, durante um semestre, fora enviada quantia muito superior a cem exemplares, para que o seu agente fizesse a distribuição entre os assinantes e redações de outros jornais, entretanto, quase ao concluirse o trimestre, foram também remetidos ao mesmo agente os recibos para que ele procedesse à cobrança, visto que o pagamento deveria ser adiantado. Diante de tal perspectiva, o semanário manifestou sua surpresa quando aquele funcionário mandou dizer que todos os assinantes negavam-se a pagar pelo motivo de que a folha rio-grandina havia muito não publicava crônicas daquele lugar, deixando por isso de interessar aos assinantes. Perante tal comentário, o periódico literário afirmava que não queria crer que entre tantas pessoas não houvesse uma que se interessasse pela literatura e que todas fossem assinantes por mera curiosidade de novidades (VIOLETA, 22 set. 1878, p. 1; $1^{\circ}$ dez. 1878 , p. 4).

O caráter artesanal e as dificuldades para a obtenção de pessoal para a realização das diversas tarefas, ficando sobrecarregados os proprietários, foram outros fatores que limitaram a ação da imprensa literária. A impossibilidade de manter uma circulação regular foi um dos elementos motivados por aqueles fatores, ocorrendo, diversas vezes, a interrupção das edições. Um exemplo de tal caso foram as escusas publicadas pela Violeta, avisando aos seus assinantes, que se tinham adiantado em pagamentos com aquela pequena empresa, que nada sofreriam os seus interesses com a interrupção que acabara de ter o jornalzinho, visto que haveria o cuidado de indenizá-los diante de tal falta. O mesmo jornal, a respeito das falhas na distribuição, avisava que estava sendo intentada a máxima responsabilidade na remessa do jornal, mas não sabia a qual fator atribuir o descaminho que o mesmo levava, pois contínuas eram as reclamações recebidas (VIOLETA, 6 abr. 1879, p. 2; $1^{\circ}$ jun. 1879, p. 1).

A respeito das rupturas na periodicidade, também a Violeta, dirigindo-se aos seus assinantes, pedia mil desculpas pela irregularidade com que ultimamente tinha sido distribuída a pequena folha. Além disso, anunciava que, com a entrada de novo mês e trimestre faria todo o possível para que não se reproduzissem tais irregularidades, esperando também não ser abandonada pelo favor público (VIOLETA, 6 jul. 1879, p. 1). O fato de o proprietário transformar-se em verdadeiro "faz tudo" a serviço da publicação, levava a que qualquer problema de saúde ou outro tipo de dificuldade provocasse uma interrupção na publicação. Os limites tecnológicos constituíam outro obstáculo enfrentado por esses jornais, como pode ser detectado no aviso publicado pelo Arauto das Letras, justificando que não fora distribuída a folha no dia anterior, conforme pretendido, em consequência de se ter quebrado, à última hora, a terceira página, diante do que manifestava seu pedido de desculpas (ARAUTO DAS LETRAS, 27 jan.1889, p. 1).

Assim, a imprensa literária teve um papel primordial na difusão da literatura e no enriquecimento cultural da província, servindo à divulgação das obras de alguns dos destacados representantes da intelectualidade gaúcha do momento. $\mathrm{O}$ jornalismo literário foi uma alternativa às práticas jornalísticas então predominantes, ligadas a um 
caráter crítico-opinativo ou essencialmente noticioso, destinando espaço a diferentes manifestações culturais e fomentando o saber, através de textos em prosa e verso e matérias educativas. A negação quanto à pasquinagem, procurando moldar o estereótipo de uma linha editorial séria, voltada essencialmente à literatura e o sem número de dificuldades enfrentadas na manutenção das diversas publicações foram apenas alguns dos fragmentos históricos a ser desvelados a partir da investigação desses periódicos que marcaram presença no Rio Grande da segunda metade do século XIX. O conjunto de tal imprensa literária teve substancial significado na constante busca dos riograndinos em construírem a imagem de uma sociedade civilizada para aquela comunidade portuária (ALVES, 2000:9-28.). Sendo a civilização o destino, o caminho para o mesmo era a literatura e os jornais literários representariam os guias naquela direção (ALVES, 2005:52-53). Tais características ficam observáveis a partir do estudo de um desses periódicos, a Inúbia que, apesar de pouco perene, bem representou o coletivo desse jornalismo literário.

A Inúbia circulou de março a novembro de 1868 e suas quatro páginas eram publicadas semanalmente aos domingos, custando sua assinatura trimestral o valor de $2 \$ 500$ réis. Seus proprietários eram empregados do Artista, jornal diário citadino em cuja tipografia também era impressa a folha literária. Em seu frontispício era estampado "periódico literário" como dístico e, quanto à redação, dizia aceitar colaborações diversas, mas, para evitar o anonimato, já no cabeçalho, anunciava que todos os escritos deveriam vir assinados e ser remetidos à tipografia do Artista. A partir de maio de 1868, revelando as dificuldades na manutenção de uma folha puramente literária, passaria a abrir espaço para matéria noticiosa e publicitária. O título da Inúbia trazia por significado uma trompa indígena de guerra, trombeta ou corneta. A partir de tal linguagem figurativa, a folha pretendia fazer ecoar certa cultura literária no contexto do extremo-sul do Brasil (ALVES, 1999b:148).

Ao apresentar-se aos leitores, a Inúbia destacava que, após ser anunciada por várias vezes, ela surgia modesta em sua origem, pois era resultado do penoso labor de quatro artistas, pretendo trilhar uma senda relativa a seus princípios. Como era comum à imprensa literária, a folha buscava esquivar-se da pasquinagem, enfatizando que não seria um reposteiro por trás do qual um anônimo viria a disparar setas falsas que pudessem ferir no coração a esta ou aquela individualidade, pretendendo respeitar a todos. A profissão de fé em prol da literatura também era expressa na apresentação do jornal, ao anunciar que o fim nobre a que se propunha era o engrandecimento da literatura, no seio da mocidade estudiosa da província. Afirmava ainda que não faria promessas, pois, despida de atavios, como uma filha da arte, pedia apoio ao respeitável público, visando conquistar um lugar muito modesto no jornalismo provincial (INÚBIA, 15 mar. 1868, p. 1).

Também no que tange a suas metas, a novel publicação literária declarava que o único lucro que almejava, a partir do cumprimento de sua tarefa, seria o de concorrer de alguma forma para a formação do panteão literário rio-grandense. Dizia que estava aberta a receber colaborações diversas, como artigos literários ou poesias, os quais seriam submetidos ao juízo crítico da comissão de redação, de modo a desenvolver os trabalhos de uma folha, não a sujeitando ao papel de reservatório de escritos capengas, aceitos e publicados muitas vezes por mera deferência a amizades. Revelando a função de divulgador de escritores regionais, o semanário anunciava que suas páginas conteriam sempre variedades, romances, poesias e crônicas de jovens rio-grandenses ou residentes na província. Além disso, apelava para a proteção dos leitores a qual poderia ser retribuída com o aumento do formato e a manutenção da circulação à medida que crescesse o número de assinantes (INÚBIA, 15 mar. 1868, p. 1).

Ainda no seu primeiro número, a Inúbia recebia saudações na forma de correspondência, desejando que ela continuasse incessantemente em sua caminhada e, com referência ao contexto provincial, era afirmado que a província assumira a dianteira, pois uma legião de jovens passara a publicar periódicos, uns que sobreviviam e outros que, com o bafejo da má sorte, despedaçavamse contra os obstáculos e peias que lhe eram impostas. Especificamente sobre o periódico literário rio-grandino, era esperada a melhor das sortes, desejando que ele se tornasse um campeão, pois fora levantado pelos reis da arte que, cheios de ardor e entusiasmo davam publicidade a um semanário cujo nome poético poderia fazer julgar aos que o recebiam que mais um facho de luz inebriante se erguia. Era também manifestado o anseio de que o jornal não deixasse que se extinguissem as suas metas, dando mais um sublime e elevado passo para o progresso das letras (INÚBIA, 15 mar. 1868, p. 2).

De acordo com sua proposta editorial, a Inúbia manteve em suas páginas sessões como "Variedade", "Álbum poético", "Romance", "Cartas críticas", "Literatura", "Poesia" e "Miscelânea" todas voltadas à edição de matérias vinculadas à divulgação de temas literários em prosa ou poesia. Ao acrescentar a meta de também ser noticiosa, além de literária, a folha passou a publicar "Apedidos", "Memorial" e "Semana crítica", destinadas à difusão de informações, além de breves notas denominadas "Movimento do porto" e "Aviso marítimo", voltadas às atividades mercantis, fundamento da economia rio-grandina e chegou mesmo a estampar alguns pouquíssimos anúncios, mormente de espetáculos 
teatrais, agências de compra de ouro, interesse pelo aluguel de uma casa e oferta dos serviços de cozinheiro por meio do aluguel de um escravo.

Ao chegar à sua décima edição, o semanário anunciava melhorias de ordem gráfica, além de retomar os intentos anunciados no número inaugural. Nesse sentido, a redação destacava que até então não haviam sido pequenos os esforços para elevar a qualidade do jornal, de modo a manter a premissa pela qual era a Inúbia uma filha da verdadeira arte, ou seja, daquela que se baseava na prosperidade pela honradez e pelo labor. Assim, anunciava que o seu formato seria aumentado e continuaria a promover tal incremento toda vez que o acolhimento do seu ilustrado público o permitisse e, em tal perspectiva, dizia ter muita fé na concretização dessa meta. A respeito de não possuir tipografia própria, afirmava que principiara como pobre órfão, sob um teto alheio, mas desejava que um dia, através do trabalho, pudesse conseguir um melhor futuro, obtendo um lar, um asilo próprio (INÚBIA, 17 maio 1868, p. 1).

Periodicamente, o jornal narrava as dificuldades enfrentadas pela pequena imprensa, notadamente no que tange à obtenção de assinantes. Dessa maneira, explicava que, quando aparecera o primeiro número da Inúbia, muitas pessoas haviam torcido o nariz, com ares de quem previa o seu próximo passamento de mal de sete dias e por isso fora-lhe negado um óbolo de assinatura, com o qual ela pudesse prosperar. Em contrapartida, destacava que a partir da boa vontade das pessoas que a apadrinharam no seu aparecimento no mundo literário, se antepusera uma barreira férrea a todos os óbices que lhe pudessem impedir a marcha progressiva, podendo manter-se sempre com a dignidade própria ao cumprimento do seu programa. O semanário mais uma vez buscava eliminar qualquer comparação com as práticas de um pasquim, declarando que não fora sorrateiramente abrigar-se no seio das famílias para envenenar reputações, nem mesmo levara más lições à juventude inexperta, intentando, pelo contrário, proporcionar a seus leitores alguns instantes de agradável e amena distração (INÚBIA, 7 jun. 1868, p. 1).

Discorrendo a respeito de suas novas propostas, ao promover mudanças editoriais, a Inúbia afirmava que, como folha crítica, se não fora ferina nas suas censuras, não pecara também por curvar-se às mesquinhas imposições desta ou daquela entidade. Além disso, retomava o programa com o qual se apresentara, dizendo que o seguira a risca e solicitando um lugarzinho muito modesto na imprensa citadina, bem como tencionando seguir sempre na sua peregrinação literária. O periódico ressaltava novamente o aumento de seu formato que fora quase impossível de ser executado, pois não contava com um número de assinaturas suficiente, ao menos para o custeio de sua publicação em prelos alheios, mas, como um filho do trabalho, diante de nada arrefecera e empreendera tal melhoria. Previa que novos melhoramentos poderiam vir a ocorrer, preferencialmente com o incremento no número de protetores, afiançando que persistiria, uma vez que não se lançara na tarefa jornalística unicamente para a obtenção de interesses pecuniários e sim por motivos morais, os quais garantiriam a sua constância (INÚBIA, 7 jun. 1868, p. 1).

Prestes a completar seu primeiro semestre de existência, o semanário lembrava que, seis meses antes, um infantil campeão, com o modesto título de Inúbia aparecera na tribuna jornalística, pedindo um humilde lugar e prometendo cumprir leal e fielmente a missão a que se propunha. Diante de tal perspectiva, o periódico confirmava que cumprira e continuaria a cumprir a sua tarefa, pois, filho do trabalho e fanático pela sublime arte de Gutenberg, não faltaria coragem para fazer com que ele se tornasse digno da proteção que o público vinha lhe prodigalizando, ao cooperar com o seu generoso óbolo para que a publicação pudesse se sustentar em prelos alheios. A folha dizia que vinha caminhado pela senda delineada pelo dever que o sacro sacerdócio da imprensa lhe impunha, rendendo homenagem à honra, incensando as virtudes e desprezando as máculas que a calúnia infiltrava. Reconhecia que, por vezes, usara da crítica sincera que apontava os erros, abandonando, entretanto, a crítica mordaz que acabrunhava as vítimas (INÚBIA, 13 set. 1868 , p. 1$)$.

Na mesma linha e mais uma vez intentando isentarse da prática da pasquinagem, o jornal afirmava que sempre buscara afastar-se das lutas com alguns de seus competidores, quando antevia inglório triunfo, porém, no momento em que algum antagonista se apresentasse, lançando a luva no vasto campo das ideias, então se mediriam os gladiadores com as polidas armas da sã inteligência. Reiterava assim que não penetrara no lar doméstico, para com a pena ensopada em fel romper o véu que encobria o seu sagrado santuário e, pelo contrário, vinha se esforçando para manter o respeito e a veneração para consigo ilesos, considerando-se merecedor dos mesmos. De acordo com tal perspectiva, o semanário esclarecia que, como obscuro operário, não seria corrompido pelo contato das mal entendidas especulações, bem como não enxergava as coisas pelo prisma do interesse e da ambição (INÚBIA, 13 set. 1868, p. 1).

Em referência aos colaboradores que enviavam escritos a serem publicados, a folha enfatizava ainda que, naqueles seis meses iniciais, não lhe faltara a graciosa proteção da mocidade inteligente, que sempre o auxiliara com o fruto de seus estudos. Além disso, o periódico afirmava que a estrela do trabalho que o guiava, servia 
para reanimar a constância, de modo que prosseguiria a Inúbia a peregrinar pelo mundo literário. Em linguagem figurada, o jornal manifestava o desejo de permanecer circulando, ao destacar que, como a florzinha que carecia de uma mão generosa que lhe regasse a planta, assim também a folha precisava da benévola proteção do público, para não ser vítima do tufão da adversidade. $\mathrm{Na}$ perspectiva de completar seu primeiro semestre, a publicação rio-grandina explicitava que o acolhimento do passado lhe servia de estímulo a uma risonha esperança no porvir (INÚBIA, 13 set. 1868, p. 1).

Os empecilhos que cercavam a imprensa literária continuavam a ser destaque nas páginas da folha riograndina. Nesse sentido, os obstáculos relacionavamse também com a dificuldade na obtenção de matérias, como no caso da descrição elaborada pelo jornal, de forma bem humorada, a respeito das peripécias de um redator para conseguir a composição de seu periódico. Diante da argumentação de que a vida dos publicistas era fácil, o jornal reagia, negando quando se tratasse de uma folha literária, se comparada aos outros gêneros em circulação à época. Destacava assim que, quando o periódico era comercial ou noticioso, a situação era mais simples, podendo-se publicar um inesgotável catálogo das chegadas e saídas de pessoas ilustres, os preços dos mais variados produtos, boatos falsos sobre a guerra, e, como sublime recurso, havia a possibilidade dos anúncios. No mesmo sentido, expunha as facilidades do redator de uma folha política, que podia proclamar, num artigo de fundo, ideias de um extremo republicanismo ou monarquismo, atacar ou elogiar o ministério e os deputados, falar da vida alheia, enfim, vociferar contra tudo. Já o redator de um periódico de tendência literária passava por problemas de bem mais difícil solução, principalmente quando os textos prometidos não eram encaminhados e, para que o jornal não ficasse incompleto, tinha de recorrer a extrações de outras folhas, atitude que, entretanto, não agradava aos leitores exigentes, fazendo com que o próprio redator, à última hora, tivesse de, por força, escrever alguma coisa (INÚBIA, 5 abr. 1868, p. 1-2).

Também no que tange aos obstáculos que se antepunham e aos mecanismos utilizados para enfrentálos, as folhas literárias tinham de adotar posturas criativas. Quanto à distribuição, a Inúbia utilizava-se de um expediente muito usual à época, enviando exemplares a possíveis leitores na tentativa de conquistá-los como assinantes. Nesse sentido, desde o seu primeiro número, instruía as pessoas que tivessem recebido o jornal e ainda não tivessem efetuado sua assinatura, caso não quisessem ser alocados entre os favorecedores, deveriam promover a devolução dos números recebidos e declarar a intenção de não receber a publicação, pois, caso contrário, seriam contemplados no rol dos assinantes, numa prática que viria a repetir-se. Outra estratégia adotada pelo semanário na busca de obter novos leitores fixos, foi anunciar que, a partir de sua décima-sétima edição, os assinantes poderiam publicar gratuitamente um anúncio do tipo comum, que não excedesse a cinco linhas, devendo os mesmos serem remetidos à redação da Inúbia, na tipografia do Artista. (INÚBIA, 15 mar. 1868, p. 1; 5 jul. 1868, p. 1 e 3).

Os avisos solicitando o pagamento das assinaturas também estiveram presentes, de modo que a folha rogava a todos os cavalheiros que haviam se dignado a aceitá-la, tivessem a bondade de mandar satisfazer a assinatura, caso contrário teria de ser suspensa a entrega do periódico. Já nas últimas edições, o apelo era ainda mais desesperado, chegando a empregar uma prática comum aos representantes da pequena imprensa ligada à ameaça de divulgar quem eram os devedores. Nesse sentido, o semanário anunciava que pela última vez rogava àqueles senhores que desde o começo da folha ainda não satisfizeram a sua assinatura, tivessem a bondade de mandar solvê-la, caso contrário, haveria a suspensão da entrega do periódico, além de serem declarados os nomes daqueles que deixaram de cumprir com o seu dever (INÚBIA, 26 jul. 1868, p. 1; 30 ago. 1868, p. 1; 13 set. 1868, p. 1).

Ainda que de uma maneira tênue e introdutória, a Inúbia publicou alguns textos voltados a uma incipiente crítica literária, analisando certos elementos constitutivos relacionados aos modos de escrever e promover a literatura de então. Em tom humilde, o periódico dizia que a sua redação e colaboração dispunham de pequeno cabedal em conhecimentos literários, mas, mesmo assim, não abriria mão de atuar como um luzeiro das letras. Uma preocupação do jornal era com a necessária compreensão do público em relação ao que se escrevia, afirmando que, muitas vezes, o leitor ficava a ver patavina a respeito do que era escrito, enquanto o escrevedor, atacado de larica literária perdia-se em divagações. A folha criticava tais escritores, denominando-os de múmias ambulantes, enfatizando que eles diziam beber no parnaso inspirações divinas e que, a cada canto das ruas, atacavam o cidadão pacífico, pedindo-lhe atenção para a leitura de um poema épico, pindárico, homérico, virgiliano, cacofônico. Eles eram ainda qualificados pelo hebdomadário como uma súcia de tipos incompreensíveis, a qual crescia como os parasitas junto de qualquer coisa que lhes pudesse dar seiva, dedicando também breves carapuças para tais tipos caricatos que invadiam o parnaso sem autorização (INÚBIA, 31 maio 1868, p. 1).

A publicação literária dizia não entender que fossem poetas unicamente aqueles que escrevessem poesias homéricas, pindáricas e virgilianas, encarando também nesse número todos aqueles que, de férula em punho, faziam análises críticas em matéria poética. Segundo 
a folha, o censor deveria conhecer e sentir a fundo os erros que apontava, sendo até muito lógico, que aquele que conhecesse as causas, também o deveria fazer em relação aos efeitos, prometendo a eles realizar as críticas de suas críticas, ainda que com o perronismo e a rabugice, próprias da idade de um Matusalém, quando a questão crítica se transformava em tréplica. A Inúbia questionava se os leitores saberiam aquilatar o quanto encerrava em si a palavrinha mirífica de escrevedor, propondo-se a acompanhar o público em tal investigação. Para o jornal não poderiam ser considerados escrevedores: o moço que, despeitado com a namorada que não lhe prestara atenção no baile, recorria às colunas dos apedidos, em uma folha e cantava-lhe vésperas sicilianas; aquele que despeitado com as feições políticas, prometia no auge de seus rancores, dar novas de sua avó-torta; ou ainda aquele que, sentado diante de um banco comercial, vendia o palito com que escrevera à entidade que lhe pagava mais caro os bons serviços, desprezando os reclamos da consciência, pois havia muito que traficava com o diabo (INÚBIA, 31 maio 1868 , p. 2).

Para a folha literária, nenhum desses casos citados poderia ser alocado na categoria dos escritores, de modo que isso seria reconhecido de parte do público perante aqueles répteis que, por mais que buscassem elevar a empeçonhada cabeça, não passavam além do pó em que se enchafurdavam. Por outro lado, o jornal argumentava que a mocidade - que sem o menor proveito pecuniário, porque ainda não se achava intrometida no mercantilismo do século, e nem o desejava-gastava as longas e penosas horas de suas vigílias em acurado estudo, na esperança de um dia ser útil ao berço que a embalara, podendo ser admitida no número dos escrevedores, mas isso só poderia ser confirmado pelo futuro, cujas portas douradas e risonhas buscava tal mocidade, conseguindo, com a sua chave de ouro, abrir também as portas do templo em que se encerravam tais mistérios (INÚBIA, 31 maio 1868, p. 2).

Em outra matéria voltada à introdutória crítica literária, o jornal apreciava com base na ironia e até com certa jocosidade, o excesso de lamúrias entre aqueles que à época se intitulavam como poetas. Nesse sentido, afirmava que os leitores poderiam percorrer as páginas de qualquer desses volumes de poesias, que sucessivamente eram publicados, e veriam que seus autores não tinham outro pensamento, que não fosse o de desgosto e aborrecimento pela vida. O periódico dizia que tal cantilena de todos os dias despertava algumas reflexões que não serviriam de corretivo para tais choramingadores, mas nem por isso deixaria de expô-los a quem quisesse ter a pachorra de lê-los. Como um motejo, a folha exclamava que tal tristeza parecia refletir o quão desgraçada seria a mocidade, destacando que, ao se tomar, ao acaso, qualquer volume, seriam encontrados logo nas primeiras páginas os doridos lamentos de uma alma, que, num vale de lágrimas de tantos milhões de habitantes, não tinha outra que a compreendesse, ficando a esperar que chegasse a sua hora derradeira, devendo Deus recompensá-la por ter andado tão sozinha no meio de tanta gente (INÚBIA, 14 jun. 1868, p. 1).

Mantendo a linha de raciocínio acerca da excessiva amargura dos escritores, a Inúbia se referia aos bardos imberbes, que não sabendo ainda o que era a vida, queixavam-se dela como cheia de dores e desgraças, proclamando-se incontinente os mais infelizes dos mortais. A folha destacava ainda os acentos apaixonados de uma alma tão cândida como um sorriso de anjo, e pura como um pensamento de Deus, a qual fora enganada, atormentada, despedaçada e aniquilada por um monstro de hipocrisia e de perfídia, ou seja, por uma mulher. Ainda ao mesmo respeito, o periódico citava as sentidas endechas daquele que só pensava na pátria querida, onde o vento ciciava, os passarinhos gorjeavam e o dia aparecia risonho e esplêndido, como uma ledice de noiva e, no entanto, tal pátria tão saudosa distava apenas uma meia dúzia de léguas de um filho tão saudoso. Explicitando o tom irônico, o jornal arrolava ainda aqueles que choravam por tudo, ou seja, pelo tempo das ilusões, que não mais voltaria, bem como pelo tempo em que mamara e apanhara borboletas e passarinhos, dizendo que a choradeira poderia continuar, não contando com seu amparo para estancar as lágrimas (INÚBIA, 14 jun. 1868, p. 1).

Em relação a tais considerações, o semanário literário concluía que todos aqueles poetas atormentados, desprezados, incompreensíveis e descrentes, viviam em prostração dolorosa, aborrecendo a sociedade, pois andavam aí por essas praias, como Ovídio escrevendo versos nas areias, como Tasso vagando de cidade em cidade, como Camões, em luta com as vagas do mar e com a miséria em terra, ou ainda como um Gonzaga na prisão e no exílio. Diante de tais possibilidades, o jornal dizia que aqueles escritores, ao contrário, andavam nos frouxos gozos, que a opulência oferecia, repotreados em êxtase inefável a ruminar na mente versos sentidos que dilaceravam os peitos daqueles que, com dor os liam. Nessa linha, a Inúbia afirmava que Ovídio, Tasso, Camões, Gonzaga e outros poderiam até chorar, porque sofreram desgraças, ao passo que não era concebível que os poetas infelizes de então chorassem daquela maneira. O periódico considerava que tal atitude era uma demasia, comparando tais escritores com algumas crianças, que não tendo motivo para chorar, choramingavam, ocultando os olhos secos com o braço esquerdo, enquanto que com a mão direita levavam à boca ótimos docinhos. Com graça, a folha concluía desejando que não houvesse choro na despedida (INÚBIA, 14 jun. 1868, p. 1). 
Através dessas breves incursões à crítica literária e, fundamentalmente, por meio da divulgação de textos literários e promovendo a difusão da leitura, a Inúbia prestou sua parcela de contribuição ao aprimoramento cultural sulino. Enquanto se manteve essencialmente literário, o semanário conseguiu garantir sua continuidade, entretanto, ao enveredar por novos caminhos, ampliando seus horizontes editoriais para também ser crítico e noticioso, sua sorte não se manteve. Progressivamente, as matérias literárias iam perdendo espaço para as noticiosas, notadamente a partir do momento em que a folha passou a divulgar informações acerca da Guerra do Paraguai, as quais se tornariam recorrentes em suas páginas. Os representantes da pequena imprensa tinham de oferecer uma proposta alternativa de leitura em relação ao público, pois, se tentassem reproduzir o norte editorial dos jornais diários, entrariam em seara alheia e não teriam condições de competir em pé de igualdade. Nesse sentido, a vocação voltada à difusão da cultura e da erudição passava a ser opção essencial à sobrevivência dos periódicos literários e a Inúbia sofreria os inevitáveis reveses de aos poucos afastar-se de tal postura, o que custou o seu desaparecimento. Apesar da curta existência, aquela trombeta voltada à difusão das letras representou muito a contento os alcances e limites do conjunto da imprensa literária naquele extremo-sul brasileiro da segunda metade do século XIX.

\section{Referências}

ALVES, Francisco das Neves. Nos limiares da civilização: a imprensa literária rio-grandina na década de 1860. Por uma história multidisciplinar do Rio Grande. Rio Grande: Universidade Federal do Rio Grande, 1999a. p. 49-51.

ALVES, Francisco das Neves. A pequena imprensa riograndina no século XIX. Rio Grande: Ed. da FURG, 1999b.

ALVES, Francisco das Neves. A imprensa literária rio-grandina na segunda metade do século XIX. Artexto - Revista do Departamento de Letras e Artes, Rio Grande, v. 11, p. 9-28, 2000.

ALVES, Francisco das Neves. $O$ discurso político-partidário sul-rio-grandense sob o prisma da imprensa rio-grandina (1868-1895). Rio Grande: Ed. da FURG, 2002.
ALVES, Francisco das Neves. A imprensa literária no sul do Brasil no século XIX. In: VAZ, Artur Emílio; BAUMGARTEN, Carlos Alexandre; CURY, Maria Zilda F. (Org.). Literatura em revista (e jornal): periódicos do Rio Grande do Sul e de Minas Gerais. Belo Horizonte: UFMG; Rio Grande: FURG, 2005. p. 27-56.

BAUMGARTEN, Carlos Alexandre; SILVEIRA, Carmen Consuelo. O Parthenon Literário: imprensa e sociedade literária. In: BAUMGARTEN, Carlos Alexandre; SILVEIRA, Carmen Consuelo; ZILBERMAN, Regina. O Parthenon Literário: poesia e prosa - antologia. Porto Alegre: EST/São Lourenço de Brindes/Instituto Cultural Português, 1980, p. 12-16.

BAUMGARTEN, Carlos Alexandre. Literatura e crítica na imprensa do Rio Grande do Sul (1868 a 1880). Porto Alegre: EST/São Lourenço de Brindes, 1982.

BAUMGARTEN, Carlos Alexandre. A Arcádia e a história literária sulina. In: ALVES, Francisco das Neves (Org.). Por uma história multidisciplinar do Rio Grande. Rio Grande: Universidade Federal do Rio Grande, 1999, p. 43-47.

CESAR, Guilhermino. História da literatura no Rio Grande do Sul. Porto Alegre: Instituto Estadual do Livro/CORAG, 2006.

RÜDIGER, Francisco Ricardo. Tendências do jornalismo. Porto Alegre: Editora da UFRGS, 2003.

SODRÉ, Nelson Werneck. A história da imprensa no Brasil. Rio de Janeiro: Mauad, 1999.

\section{Fontes}

ARAUTO DAS LETRAS. Rio Grande, 13 ago.1882. A. 1. N. 2. p. 1.; e 27 jan.1889. A. 3. N. 3. p. 1.

ARCÁDIA. Rio Grande, 12 maio 1867. 1a Série. p. 5-7.; 1867 (última edição da $1^{\text {a }}$ Série). p. 299-302.; 16 fev. 1868. $2^{\text {a }}$ Série. p. 5-7.; e 19 jul. 1869. 3a Série. p. 300-302.

O RECREIO. Rio Grande, 18 ago. 1901. A. 1. N. 1. p. 1.

VIOLETA. Rio Grande, 22 set. 1878. A. 1. N. 28. p. 1-2.; 1으 dez. 1878. A. 1. N. 37. p. 4.; 6 abr. 1879. A. 2. N. 43. p. 2.; $1^{\text {o jun. }}$ 1879. A. 2. N. 49. p. 1.; e 6 jul. 1879. A. 2. N. 52. p. 1.

INÚBIA. Rio Grande, 15 mar. 1868. A. 1. N. 1. p. 1-2.; 5 abr. 1868. A. 1. N. 4. p. 1-2.; 17 maio 1868. A. 1. N. 10. p. 1.; 31 maio 1868. A. 1. N. 12. p. 1-2.; 7 jun. 1868. A. 1. N. 13. p. 1.; 14 jun. 1868 . A. 1. N. 14. p. 1.; 5 jul. 1868. A. 1. N. 17. p. 1 e 3.; 26 jul. 1868. A. 1. N. 20. p. 1.; 30 ago. 1868. A. 1. N. 25. p. 1.; e 13 set. 1868 . A. 1. N. 27. p. 1.

Recebido: 09 de setembro de 2014 Aprovado: 20 de janeiro de 2015 Contato: fnah@vetorial.net 